\title{
OGRANICZENIE SAMODZIELNOŚCI SAMORZĄDU TERYTORIALNEGO W STANACH NADZWYCZAJNYCH - WYBRANE PROBLEMY
}

\begin{abstract}
W artykule dokonano analizy regulacji normatywnych obejmujących procedurę wprowadzania stanów nadzwyczajnych (stanu wojennego, stanu wyjątkowego oraz stanu klęski żywiołowej) w Polsce oraz wynikających z tego konsekwencji i zmian w obszarze kompetencji, systemu oraz zasad działania organów administracji publicznej ze szczególnym uwzględnieniem ograniczenia samodzielności i niezależności zdecentralizowanego samorządu terytorialnego. Rozważania obejmują również zagadnienia związane $\mathrm{z}$ problemem funkcjonowania jednostek samorządu terytorialnego jako samodzielnych i niezależnych podmiotów prawa publicznego. Problematyka ta została poddana analizie na podstawie literatury przedmiotu oraz orzecznictwa Trybunału Konstytucyjnego. W dalszej części opracowania skoncentrowano się na procedurze wprowadzania poszczególnych stanów nadzwyczajnych oraz konstytucyjnie określonych przesłankach ich wprowadzenia. Zasadnicza cześć artykułu obejmuje analizę zmian, jakie przewidział ustawodawca $\mathrm{w}$ zasadach funkcjonowania organów samorządu terytorialnego $\mathrm{w}$ czasie trwania każdego ze stanów nadzwyczajnych. Rozważania w tym obszarze skoncentrowano na poszczególnych przypadkach utraty konstytucyjnie gwarantowanej samodzielności jednostek samorządu terytorialnego oraz przewidzianej w ustawach o stanach nadzwyczajnych konstrukcji podporządkowania tych jednostek organom scentralizowanej administracji rządowej. W artykule omówiono wybrane przykłady regulacji, na mocy których wojewoda, jako terenowy organ administracji rządowej, uzyskuje uprawnienia do kierowania działaniami organów samorządu terytorialnego, a także uprawnienia do wprowadzenia w stosunku do jego organów nadzwyczajnych, personalnych środków nadzoru. Rozważania w tym obszarze mają charakter porównawczy i obejmują również postanowienia przepisów prawa regulujących zasady funkcjonowania administracji publicznej $\mathrm{w}$ warunkach standardowego funkcjonowania państwa, kiedy nie występuja zagrożenia o charakterze szczególnym. Opracowanie kończą podsumowanie oraz wnioski będące efektem przeprowadzonej w artykule analizy.

Slowa kluczowe: samorząd terytorialny, stany nadzwyczajne, legalność
\end{abstract}

I. Przeprowadzone w Polsce w latach dziewięćdziesiątych ubiegłego wieku reformy systemu administracji publicznej ustaliły ostateczny, trójstopniowy model administracji samorządowej. Na skutek tych działań gwarantowana konstytucyjnie, dualistyczna struktura administracji publicznej uzyskała swój specyficzny wymiar w województwach, w których obok scentralizowanych organów administracji rządowej realizują swe zadania również zdecentralizowane organy samorządu terytorialnego. Powołanie zdecentralizowanych jednostek samorządu terytorialnego i uznanie tych

\footnotetext{
${ }^{1}$ Dr Małgorzata Polinceusz, Katedra Prawa i Administracji, Wydział Zarządzani, al. Powstańców
} Warszawy 6, 35-959 Rzeszów, tel. (0-17) 85244 42, e-mail: malgpope@prz.edu.pl 
jednostek za samodzielne podmioty prawa publicznego oznaczało konieczność określenia istoty samodzielności tych jednostek oraz wyznaczenia jej faktycznego zakresu. W konsekwencji wiązało się to również z koniecznością określenia na nowo wzajemnych relacji organów administracji rządowej i samorządowej.

Wielu przedstawicieli doktryny podkreśla nierozerwalne więzi łączące samodzielność i decentralizację. Już J.Starościak traktował samodzielność jako podstawowy wyznacznik decentralizacji ${ }^{2}$. Podobnie w opinii J. Szreniawskiego decentralizacja to oparta na prawie samodzielność działania ${ }^{3}$. J. Boć zauważa, że samodzielność jest konstytutywnym elementem decentralizacji i to niezależnie od swoistości ustroju politycznego, w ramach którego ona zachodzi ${ }^{4}$.

Samodzielność jednostek samorządu terytorialnego określana jest na wiele sposobów. Na przykład według El. i Ed. Ura samodzielność samorządu wyraża się przede wszystkim w możliwości samokształtowania ustroju wewnętrznego jednostek samorządu, w ich samodzielności finansowej, majątkowej oraz samodzielności wykonywania zadań publicznych służących zaspokajaniu potrzeb wspólnoty ${ }^{5}$. Z kolei zdaniem M. Miemca społeczności samorządowe - W zakresie określonym prawem - mają pełną swobodę działania w każdej sprawie, która nie jest wyłączona spod ich kompetencji lub która nie koliduje $\mathrm{z}$ zakresem kompetencji innych organów władzy. Autor podkreśla, że uprawnienia przyznane samorządowi terytorialnemu powinny być pełne i całościowe, a przypadki ich przejęcia czy ograniczenia mogą zachodzić wyłącznie w granicach określonych ustawą ${ }^{6}$.

W pojmowaniu istoty samodzielności jednostek samorządu terytorialnego istotną rolę odegrało również orzecznictwo Trybunału Konstytucyjnego (TK). W uzasadnieniu jednego z orzeczeń Trybunału Konstytucyjnego z 4 maja 1998 r. zaznaczono, że zasada decentralizacji władzy publicznej oraz uczestniczenie przez samorząd w wykonywaniu znacznej części zadań publicznych wynikają z organizacji i ustroju całego państwa. Zdaniem Trybunału Konstytucyjnego istotą samorządu, jako odrębnego podmiotu publicznego w państwie, jest właśnie jego samodzielność, która jako wartość chroniona lecz nie absolutna - może podlegać różnego rodzaju ograniczeniom ${ }^{7}$. Samodzielność jednostek samorządu terytorialnego nie wyklucza więc podporządkowania ich działalności przepisom prawa, a ochrona tej samodzielności nie może w nadmiernym stopniu ograniczać czy też znosić prawa ustawodawcy do kształtowania stosunków w państwie. Trybunał zaznaczył jednak, że ingerencja ustawodawcy w sferę samodzielności samorządu nie może być nadmierna oraz zawsze musi znajdować swe uzasadnienie w konstytucyjnie określonych celach i chronionych wartościach, których przedkładanie nad zasadę ochrony samodzielności jednostek samorządu terytorialnego zależy od oceny

\footnotetext{
2 J. Starościak, Decentralizacja administracji publicznej, Warszawa 1960, s. 10-11.

${ }^{3}$ J. Szreniawski, Zarys nauki administracji, Lublin 2000, s. 59.

${ }^{4}$ J. Boć, Decentralizacja, [w:] Administracja publiczna, red. A. Błaś, J. Boć, J. Jeżewski, Kolonia Limited 2003, s. 186.

5 E. Ura, Ed. Ura, Prawo administracyjne, Rzeszów 2004, s. 165-166.

6 M. Miemiec, Nadzór nad działalnościa gminną, działalnościq powiatu oraz działalnościa samorzadu województwa, [w:] Prawo administracyjne, red. Boć J., Wrocław 2007, s. 237.

${ }^{7}$ Wyrok TK z 4 maja 1998 r., K 38/97. Opubl.: OTK 1998, nr 3, poz. 31. Źródło: legalis.
} 
ustawodawcy ${ }^{8}$. Istotne jednak jest to, aby wszelkie środki ingerencji stosowane wobec zdecentralizowanego podmiotu były ustawowo określone i aby podstawa prawna stanowiąca umocowanie tej ingerencji nie była poddawana interpretacji rozszerzającej ${ }^{9}$.

Należy dodać, że granice niezależności oraz samodzielności realizacji zadań przez samorząd terytorialny wyznaczają kryteria sprawowanego nad nim nadzoru, który ma między innymi gwarantować jedność i legalność działania zdecentralizowanych organów samorządowych. Nadzór stanowi tu bowiem niezbędny element koordynacji działań wszystkich podmiotów prawa publicznego - zarówno tych działających na zasadzie decentralizacji, jak i tych, które tworzą strukturę administracji scentralizowanej - a ponadto odgrywa on wyjątkowo ważną rolę, ponieważ ograniczając możliwość ingerencji w działania jednostek samorządu terytorialnego, chroni jednocześnie ich samodzielność oraz zapewnia realizację zasady praworządności $i^{10}$.

II. Jak już podkreślono, utworzenie samorządu terytorialnego oraz przekazanie mu do samodzielnej realizacji grupy zadań publicznych wiąże się jednocześnie $\mathrm{z}$ koniecznością zastrzeżenia możliwości wpływu struktur rządowych (scentralizowanych) na jego działalność. Ich oddziaływanie ma za zadanie zabezpieczyć i jednocześnie stanowić gwarancję legalnego, sprawnego i wysoce efektywnego procesu realizacji przypisanych mu zadań - szczególnie w zakresie ochrony wartości najwyższych, takich jak życie, zdrowie i bezpieczeństwo obywateli.

W związku z tym utrwalona i gwarantowana konstytucyjnie zasada samodzielności działania samorządu terytorialnego ulega znaczącej rekonstrukcji w wypadku wystąpienia szczególnych zagrożeń dla państwa, wynikających $\mathrm{z}$ wewnętrznego, zewnętrznego zagrożenia bezpieczeństwa, a także na skutek działania sił przyrody. Mając na uwadze przypisaną przez Konstytucję $\mathrm{RP}^{11}$ państwu rolę, musi ono sprawnie funkcjonować nie tylko w sytuacjach kryzysowych, czyli warunkach zasadniczo zwykłych zagrożeń bezpieczeństwa państwa $\mathrm{i}$ obywateli ${ }^{12}$, ale również $\mathrm{w}$ warunkach wystąienia zagrożeń szczególnego rodzaju, które uzasadniają wprowadzenie jednego ze stanów nadzwyczajnych ${ }^{13}$.

\footnotetext{
${ }^{8}$ Por. orzeczeniu TK z 23 października 1996 r., sygn. K 1/96, OTK 1996, t. II, poz. 36, oraz wyrok z 15 grudnia 1997 r., sygn. K/13/97, OTK ZU nr 5-6 [14-15], poz. 97.

${ }^{9}$ J. Filipek, Prawo administracyjne. Instytucje ogólne, Kraków 1995, s. 80.

10 Szerzej: M. Polinceusz, Nadzór nad administracja publiczna, [w:] Administracja publiczna i prawo administracyjne $w$ zarysie, red. M. Karpiuk, J. Kowalski, Warszawa-Poznań 2013, s. 311 i $\mathrm{n}$.

${ }^{11}$ Konstytucja Rzeczypospolitej Polskiej z 2 kwietnia 1997 r., DzU 1997 nr 78, poz. 483 ze zm., dalej jako: Konstytucja RP.

${ }^{12}$ Szerzej na temat pojęcia bezpieczeństwa: M. Popek, Kompetencje wojewody w świetle nowej ustawy

o Państwowym Ratownictwie Medycznym - wybrane zagadnienia, Materiały III Międzynarodowej Konferencji Naukowej „Prawno-ekonomiczne i techniczne aspekty bezpieczeństwa w ruchu drogowym", Rzeszów-Krasiczyn 27-30 maja 2007, Rzeszów 2007, s. 399-405; I. Oleksiewicz, M. Popek, Ewolucja kompetencji wojewody - organu realizujacego zadania z zakresu ochrony $i$ bezpieczeństwa publicznego, [w:] Bezpieczeństwo i zagrożenia współczesnego świata, red. A. Olak, I. Oleksiewicz, Rzeszów 2008, s.144-163.

${ }^{13}$ W świetle wyroku Trybunały Konstytucyjnego z 21 kwietnia 2009 r. (OTK-A 2009/4/51, DzU $2009 \mathrm{nr}$ 65, poz. 553) Konstytucja wyznacza granice pomiędzy stanami nadzwyczajnymi a
} 
Stan nadzwyczajny stanowi odzwierciedlenie stanu szczególnego zagrożenia dla porządku i bezpieczeństwa publicznego lub też samego istnienia państwa. Z założenia stanu tego szczególnego zagrożenia nie da się usunąć czy też mu zapobiec, wykorzystując zwykłe, polityczno-administracyjne środki konstytucyjne ${ }^{14}$. Należy dodać, że sprawowanie przez organy administracji publicznej (zarówno przez organy administracji rządowej jak i organy samorządu terytorialnego) zadań w ramach przepisanych ustawowo kompetencji w sytuacji wprowadzenia jednego ze stanów nadzwyczajnych ma wyjątkowy charakter i ma zmierzać przede wszystkim do stabilizacji struktur państwa oraz do ochrony porządku i bezpieczeństwa publicznego ${ }^{15}$.

Przyczyny wprowadzenia stanu wyjątkowego są zawsze takie same - sytuacje szczególnych zagrożeń, jednak ocenę stanu faktycznego oraz jego kwalifikację ustawodawca pozostawił wskazanym w Konstytucji RP organom ${ }^{16}$. W świetle art. 228 Konstytucji RP w wypadku wystąpienia sytuacji szczególnych zagrożeń, jeśli zwykłe środki konstytucyjne są niewystarczające, może zostać wprowadzony odpowiedni (w zależności od źródeł występujących zagrożeń) stan nadzwyczajny: stan wojenny, stan wyjątkowy lub stan klęski żywiołowej.

Zgodnie z treścią art. 229 Konstytucji RP w razie zewnętrznego zagrożenia państwa, zbrojnej napaści na terytorium Rzeczypospolitej Polskiej lub gdy $z$ umowy międzynarodowej wynika zobowiązanie do wspólnej obrony przeciwko agresji, Prezydent Rzeczypospolitej na wniosek Rady Ministrów może wprowadzić stan wojenny na części albo na całym terytorium państwa. Przesłanki wprowadzenia tego stanu nadzwyczajnego doprecyzowano w art. 2 ust. 1 ,Ustawy z 29 sierpnia 2002 r. o stanie wojennym oraz o kompetencjach Naczelnego Dowódcy Sił Zbrojnych i zasadach jego podległości konstytucyjnym organom Rzeczypospolitej Polskiej"17, który przewiduje również możliwość wprowadzenia stanu wojennego w wypadku zewnętrznego zagrożenia państwa spowodowanego działaniami terrorystycznymi. Natomiast w wypadku zagrożenia konstytucyjnego ustroju państwa, bezpieczeństwa obywateli lub porządku publicznego (w tym również spowodowanego działaniami terrorystycznymi) Prezydent Rzeczypospolitej na wniosek Rady Ministrów może wprowadzić, na czas oznaczony, nie dłuższy niż 90 dni, stan wyjątkowy na części albo na całym terytorium państwa ${ }^{18}$. Trzeci ze stanów nadzwyczajnych - stan klęski żywiołowej - wprowadzany przez Radę Ministrów na

„,normalnym” funkcjonowaniem państwa. „Sytuacja kryzysowa” - przez którą należy obecnie rozumieć sytuację negatywnie wpływającą na poziom bezpieczeństwa ludzi, mienia w znacznych rozmiarach lub środowiska, wywołującą znaczne ograniczenia w działaniu właściwych organów administracji publicznej ze względu na nieadekwatność posiadanych sił i środków - jest czymś rodzajowo odmiennym od konstytucyjnych stanów nadzwyczajnych. W związku z tym powinna zostać zaliczona do „normalnego” funkcjonowania państwa.

${ }^{14}$ P. Florjanowucz-Błachut, P. Mikuli, Regulacja stanów nadzwyczajnych $w$ polskim prawie konstytucyjnym, [w:] Zarzadzanie kryzysowe w samorzadzie. Podstawy organizacyjno-prawne, red. A. Kurkiewicz, Warszawa 2008, s. 27.

${ }^{15}$ S. Pieprzny, Stany nadzwyczajne w Polsce a prawa $i$ wolności obywatelskie, „Zeszyty Naukowe Wyższej Szkoły Informatyki, Zarządzania i Administracji w Warszawie” 1/11 (2010), s. 132.

${ }^{16}$ Ibidem.

${ }^{17}$ DzU 2002 nr 156, poz. 1301 ze zm., dalej jako: u.s.woj.

${ }^{18}$ Art. 230 ust. 1 Konstytucji RP w zw. z art. 2 ust. 1 ustawy z 21 czerwca 2002 r. o stanie wyjątkowym (DzU $2002 \mathrm{nr}$ 113, poz. 985 ze zm.), dalej jako: u.s.wyj. 
części albo na całym terytorium państwa ma służyć zapobieżeniu oraz usunięciu skutków katastrof naturalnych lub awarii technicznych noszących znamiona klęski żywiołowej ${ }^{19}$.

Podstawową $\mathrm{i}$ ogólną zasadą wynikającą z przepisów wszystkich trzech ustaw regulujących funkcjonowanie administracji publicznej w czasie trwania każdego ze stanów nadzwyczajnych jest, że organy władzy publicznej działają w dotychczasowych strukturach organizacyjnych państwa $\mathrm{i}$ w ramach przysługujących im kompetencji. Jednocześnie ustawodawca każdorazowo zastrzega, że na mocy regulacji przedmiotowych ustaw mogą jednak zostać wprowadzone zmiany w dotychczasowym (standardowym) zakresie oraz trybie działania poszczególnych organów administracji publicznej. Zastrzeżenia te mają umożliwić podjęcie działań stanowiących właściwą reakcję na zaistniałe zagrożenia polegającą między innymi na zmianie konstytucyjnych stosunków władzy w państwie.

Zmiana ta - w wypadku każdego z trzech stanów nadzwyczajnych - charakteryzuje się przede wszystkim wzmocnieniem pozycji władzy wykonawczej i uprawnień organów administracji rządowej $\mathrm{w}$ stosunku do pozostałych podmiotów. W związku $\mathrm{z}$ tym samorząd terytorialny w czasie trwania każdego ze stanów nadzwyczajnych traci w znacznym stopniu przywilej niezależności od administracji rządowej, a w obszarze zwalczania zaistniałego zagrożenia co do zasady staje się podległy jej organom ${ }^{20}$.

Na przykład jednym z przejawów ograniczenia samodzielności jednostek samorządu terytorialnego jest powierzenie $\mathrm{w}$ czasie trwania stanu wojennego wojewodzie (scentralizowanemu organowi administracji rządowej realizującemu funkcje przedstawiciela Rady Ministrów) kierownictwa nad często niezależnymi dotychczas podmiotami w zakresie wykonywania zadań obronnych i obroną cywilną w województwie ${ }^{21}$. Należy podkreślić, że kierownictwo jako najmocniejsza $\mathrm{z}$ więzi łączących organy administracji publicznej oznacza możliwość bezpośredniej ingerencji w działania kierowanego podmiotu. Oznacza to, że organ kierujący, mając jednocześnie możliwość kontrolowania oraz nadzorowania podległych mu podmiotów, może również swobodnie używać wszelkich środków w celu bezpośredniego oddziaływania na ich postępowanie, polegających na przykład na wydawaniu wiążących wytycznych, poleceń. Organ wykonujący kompetencje kierownicze nie może jedynie używać tych środków kierowania, które przez prawo są zabronione ${ }^{22}$.

Przepisy ustawy o stanie wojennym, wprowadzając wprost zasadę podporządkowania jednostek organizacyjnych wojewodzie, jednocześnie legalizują możliwość nakładania przez wojewodę dodatkowych zadań na jednostki samorządu terytorialnego, w tym także nakaz dokonywania przez nie określonych wydatków. W zakresie tych działań

\footnotetext{
${ }^{19}$ Art. 232 Konstytucji RP w zw. z art. 2 ustawy z 18 kwietnia 2002 r. o stanie klęski żywiołowej (DzU $2002 \mathrm{nr}$ 62, poz. 558), dalej jako: u.s.k.ż.

${ }^{20}$ M.P. Gapski, Wplyw wprowadzenia stanu wojennego na relacje miedzy administracją rzadowa a samorządem, [w:] Bezpieczeństwo Polski. Historia i współczesność, red. L. Antonowicz, T. Guz, M. R. Pałubska, Lublin 2010, s. 408.

${ }^{21}$ Art. 13 ust. 1 u.s.woj.

${ }^{22}$ Szerzej: M. Polinceusz, Nadzór nad..., s. 313; M. Polinceusz, Więzi prawne wyznaczające granice kompetencji wojewody - organu realizujacego zadania $w$ zakresie ochrony bezpieczeństwa $i$ porządku publicznego, [w:] Wspólna polityka bezpieczeństwa i obronności. Implikacje dla Polski, red. A. Letkiewicz, Z. Nowakowski, J. Rajchel, Warszawa 2011, s. 656 i n.
} 
wojewodzie są podporządkowane wszystkie jednostki organizacyjne administracji rządowej i samorządowej działające na obszarze województwa oraz inne siły i środki wydzielone do jego dyspozycji i skierowane do wykonywania zadań związanych z obroną państwa i województwa, a także związanych z obroną cywilną ${ }^{23}$.

Należy podkreślić, że przedstawiona konstrukcja polegająca na podporządkowaniu jednostek samorządu terytorialnego wojewodzie (oczywiście w ramach wykonywania określonych działań) stanowi istotne odstapienie od zwykłych relacji łączących samorząd terytorialny $\mathrm{i}$ administrację rządową. Zgodnie $\mathrm{z}$ gwarantowanymi normatywnie zasadami funkcjonowania państwa sprawowanie kierownictwa wobec zdecentalizowanych jednostek samorządu jest wykluczone, gdyż sama istota samorządu i wynikająca z niej samodzielność wchodzących w jego skład jednostek w oczywisty sposób sprzeciwia się zastosowaniu tego typu form oddziaływania ${ }^{24}$.

Ustawa o stanie wojennym, podobnie jak ustawa o stanie wyjątkowym przewidują także dodatkowy - choć w swej konstrukcji już znany samorządowym ustawom ustrojowym - środek nadzoru personalnego, jakim jest zawieszenie organów samorządu terytorialnego $\mathrm{i}$ wprowadzenie zarządu komisarycznego ${ }^{25}$. Jeżeli $\mathrm{w}$ ocenie wojewody organy gminy, powiatu lub samorządu województwa nie wykazują dostatecznej skuteczności w wykonywaniu zadań publicznych lub w realizacji działań wynikających z przepisów o wprowadzeniu stanu wojennego czy też wyjątkowego, Prezes Rady Ministrów, na wniosek właściwego wojewody, może zawiesić te organy do czasu zniesienia stanu nadzwyczajnego lub na czas określony i ustanowić w ich miejsce zarząd komisaryczny sprawowany przez komisarza rządowego, powoływanego i odwoływanego na wniosek wojewody przez Prezesa Rady Ministrów.

Najdalej posunięte ograniczenia zasady samodzielności działania poszczególnych jednostek samorządu terytorialnego w czasie trwania stanu nadzwyczajnego przewidują postanowienia ustawy o stanie klęski żywiołowej. Na mocy jej postanowień w czasie stanu klęski żywiołowej działaniami prowadzonymi w celu zapobieżenia skutkom klęski żywiołowej lub w celu ich usunięcia kierują w zależności od obszaru objętego stanem nadzwyczajnym: wójt, burmistrz lub prezydent miasta, starosta, wojewoda lub też minister właściwy do spraw administracji publicznej ${ }^{26}$. W przypadku gdy stan klęski żywiołowej wprowadzono na obszarze więcej niż jednej gminy, wójt (burmistrz, prezydent miasta) kierujący na swoim terenie działaniami zmierzającymi do zapobieżenia lub usunięcia skutków klęski żywiołowej podlega staroście ${ }^{27}$. Podobną zasadę podległości ustawodawca przewidział dla wykonujących swoje zadania w tym obszarze starostów. W przypadku gdy stan klęski żywiołowej wprowadzono na obszarze więcej niż jednego powiatu wchodzącego $\mathrm{w}$ skład województwa, realizujący wynikające $\mathrm{z}$ ustawy o stanie klęski żywiołowej zadania starosta podlega wojewodzie ${ }^{28}$. W tym wypadku ustawodawca przewidział podległość starosty terenowemu, scentralizowanemu organowi administracji rządowej.

\footnotetext{
${ }^{23}$ Art. 13 ust. 2 u.s.woj.

${ }^{24}$ M.P. Gapski, op. cit., s. 409.

${ }^{25}$ Art. 14 u.s.woj. i art. 12 u.s.wyj.

${ }^{26}$ Art. 8 u.s.k.ż.

${ }^{27}$ Art. 9 ust. $1-4 \mathrm{w} \mathrm{zw} . \mathrm{z}$ art. 8 pkt. $2-4$ u.s.k.ż.

${ }^{28}$ Ibidem, art. 10 ust. $1-4$ w zw. $\mathrm{z}$ art. 8 pkt. 3 i 4.
} 
Należy podkreślić, że ustanowienie tego schematu podległości wójta staroście oraz starosty wojewodzie stanowi zupełnie odmienną od standardowej konstrukcję struktury organizacyjnej $\mathrm{w}$ administracji publicznej $\mathrm{i}$ jest istotnym odstąpieniem od zwykłych relacji między jednostkami administracji samorządowej oraz między samorządem terytorialnym a administracją rządową. Respektowanie w czasie „normalnego funkcjonowania państwa" jakichkolwiek form podległości między jednostkami samorządu terytorialnego oraz między jednostkami samorządu terytorialnego a wojewodą jest wykluczone. Sama istota samorządu terytorialnego sprzeciwia się stosowaniu tego typu schematów.

Ustawa o stanie klęski żywiołowej wprowadza także kolejne - odmienne od tych określonych w samorządowych ustawach ustrojowych - środki nadzoru nad działalnością jednostek samorządu terytorialnego przysługujące staroście oraz wojewodzie. W świetle postanowień art. 96 ust. 2 u.s.g. ${ }^{29}$, art. 83 ust. 2 u.s.p. ${ }^{30}$ i art. 84 ust. 2 u.s.w. jedynym środkiem o charakterze personalnym przysługującym wojewodzie w ramach sprawowanego przez niego nadzoru jest możliwość wystąpienia do Prezesa Rady Ministrów z wnioskiem o odwołanie odpowiednio: wójta, zarządu powiatu lub zarządu województwa. Wniosek ten może być złożony przez wojewodę w sytuacji, gdy organ wykonawczy jednostki samorządu terytorialnego dopuszcza się powtarzającego się naruszenia postanowień prawa. Warunkiem wystąpienia przez wojewodę do Prezesa Rady Ministrów z wnioskiem o odwołanie wymienionych organów jest odpowiednio: konieczność wezwania przez wojewodę wójta do zaprzestania naruszeń czy też wezwanie rady powiatu lub sejmiku województwa do zastosowania niezbędnych środków (art. 96 ust. 2 u.s.g., art. 83 ust. 2 u.s.p. i art. 84 ust. 2 u.s.w. ${ }^{31}$ ). Dopiero gdy wezwanie to nie przynosi skutku, aktualizuje się uprawnienie wojewody do złożenia wniosku ${ }^{32}$.

Odmienną procedurę przewiduje ustawa o stanie klęski żywiołowej, w świetle której wojewoda ma bezpośrednio możliwość zawieszenia uprawnień wójta lub też starosty niezdolnych do kierowania lub kierujących niewłaściwie na swoim obszarze działaniami podejmowanymi w celu zapobieżenia skutkom klęski żywiołowej lub ich usunięcia oraz wyznaczenia w ich miejsce pełnomocnika do kierowania tymi działaniami ${ }^{33}$. Zawieszenie w ten sposób części uprawnień organów samorządowych i możliwość powołania w ich miejsce pełnomocnika właściwego do realizacji tych zadań możliwe jest więc w sytuacji ich nieefektywnego lub niewłaściwego działania i opiera się na nieprzewidzianym w art. 171 ust. 1 Konstytucji RP kryterium celowości czy też skuteczności. Ocena sposobu realizacji zadań nałożonych na wójta oraz starostę postanowieniami ustawy o stanie klęski żywiołowej będzie więc przede wszystkim zależna od opinii właściwego miejscowo wojewody.

\footnotetext{
${ }^{29}$ Ustawa z 8 marca 1990 r. o samorządzie gminnym, tj. DzU 2001 nr 142, poz. 1591 ze zm., dalej jako: u.s.g.

${ }^{30}$ Ustawa z 5 czerwca 1998 r. o samorządzie powiatowym, tj. DzU 2001 nr 142, poz. 1592, dalej jako: u.s.p.

${ }^{31}$ Ustawa z 5 czerwca 1998 r. o samorządzie województwa, tj. Dz.U. 2001 nr 142, poz. 1590, dalej jako: u.s.w.

${ }^{32}$ M. Polinceusz, Nadzór nad..., s. 318 i n.

${ }^{33}$ Art. 9 ust. 5 u.s.k.ż. i art. 10 ust. 5 u.s.k.ż.
} 
III. Wystąpienie nadzwyczajnych okoliczności skutkujących wprowadzeniem stanu nadzwyczajnego niewątpliwie uzasadnia tymczasową zmianę sposobu funkcjonowania państwa oraz głębszą ingerencję w funkcjonowanie organów samorządu terytorialnego. Ograniczenia samodzielności i niezależności zdecentalizowanego samorządu terytorialnego podyktowane są koniecznością ochrony wartości najwyższych, takich jak obrona państwa, jego demokratycznego porządku konstytucyjnego, ochrona życia i zdrowia jego obywateli, a także mienia, porządku i bezpieczeństwa publicznego. Ponieważ ochrona tych wartości coraz częściej postrzegana jest w wymiarze lokalnym, normatywnie określone zasady zmian w sposobie działania organów administracji publicznej zmierzają przede wszystkim do ograniczenia swobody działania organów samorządu terytorialnego i poddania ich bezpośredniemu wpływowi scentralizowanych organów administracji rządowej. Te z kolei wyposażono w uprawnienia kierownicze oraz nadzwyczajne środki nadzoru $\mathrm{w}$ stosunku do organów samorządu terytorialnego. Realizacja w zadań w tak skonstruowanym systemie administracji publicznej niemalże czyni z dotychczas samodzielnych i niezależnych jednostek samorządu terytorialnego część scentralizowanego układu administracyjnego. Należy jednak pamiętać, że konstrukcja ta może mieć wyłącznie tymczasowy i nadzwyczajny charakter oraz stanowić ma gwarancję wysokiego stopnia efektywności realizowanych zadań.

\section{LITERATURA}

[1] Boć J., Decentralizacja, [w:] Administracja publiczna, red. A. Błaś, J. Boć, J. Jeżewski, Kolonia Limited 2003.

[2] Filipek J., Prawo administracyjne. Instytucje ogólne, Kraków 1995.

[3] Florjanowucz-Błachut P., Mikuli P., Regulacja stanów nadzwyczajnych w polskim prawie konstytucyjnym, [w:] Zarządzanie kryzysowe w samorzadzie. Podstawy organizacyjno-prawne, red. A. Kurkiewicz, Warszawa 2008.

[4] Gapski M.P., Wplyw wprowadzenia stanu wojennego na relacje miedzy administracja rządowa a samorząem, [w:] Bezpieczeństwo Polski. Historia $i$ współczesność, red. L. Antonowicz, T. Guz, M. R. Pałubska, Lublin 2010.

[5] Miemiec M., Nadzór nad działalnościa gminna, działalnościa powiatu oraz działalnościa samorządu województwa, [wPrawo administracyjne, :] red. Boć J., Wrocław 2007.

[6] Oleksiewicz I., Popek M., Ewolucja kompetencji wojewody - organu realizujacego zadania z zakresu ochrony i bezpieczeństwa publicznego, [w:] Bezpieczeństwo i zagrożenia współczesnego świata, red. A. Olak, I. Oleksiewicz, Rzeszów 2008.

[7] Pieprzny S., Stany nadzwyczajne w Polsce a prawa $i$ wolności obywatelskie, „Zeszyty Naukowe Wyższej Szkoły Informatyki, Zarządzania i Administracji w Warszawie" 1/11 (2010).

[8] Polinceusz M., Więzi prawne wyznaczajace granice kompetencji wojewody organu realizujacego zadania $w$ zakresie ochrony bezpieczeństwa $i$ porzadku publicznego, [w:] Wspólna polityka bezpieczeństwa i obronności. Implikacje dla Polski, red. A. Letkiewicz, Z. Nowakowski, J. Rajchel, Warszawa 2011. 
[9] Polinceusz M., Nadzór nad administracja publiczna, [w:] Administracja publiczna i prawo administracyjne $w$ zarysie, red. M. Karpiuk, J. Kowalski, Warszawa-Poznań 2013.

[10] Popek M., Kompetencje wojewody w świetle nowej ustawy o Państwowym Ratownictwie Medycznym - wybrane zagadnienia, Materiały III Międzynarodowej Konferencji Naukowej „Prawno-ekonomiczne i techniczne aspekty bezpieczeństwa w ruchu drogowym”, Rzeszów-Krasiczyn 27-30 maja 2007, Rzeszów 2007.

[11] Starościak J., Decentralizacja administracji publicznej, Warszawa 1960.

[12] Szreniawski J., Zarys nauki administracji, Lublin 2000.

[13] Ura E., Ura Ed., Prawo administracyjne, Rzeszów 2004.

\section{REDUCING THE INDEPENDENCE OF LOCAL GOVERNMENT IN} EMERGENCY SITUATIONS - THE SELECTED PROBLEMS

This article analyzes the normative regulations covering the procedure for states of emergency (martial law, state of emergency and the state of natural disaster) in Poland and the resulting consequences of this fact and changes in the area of competence of the system and principles of the public administration with particular regard to the reduction of autonomy and independence of the decentralized local government. The considerations also include the issues related to the problem in the functioning of local government units as separate and independent entities of public law. This issue has been analyzed based on the literature and the case law of the Constitutional Court. The next part of the paper concentrates on the procedure for the introduction of individual states of emergency and constitutionally defined grounds for introducing them. The main part of the article includes an analysis of the changes that the legislature foresaw in the rules of functioning of the local government authorities for the duration of each state of emergency. Considerations in this area were focused on individual cases, the loss of constitutionally guaranteed autonomy of local government units and predicted in the statutes construction of subordinate bodies to the units of the centralized government. The article discusses some examples of regulation under which the province governor, as the terrain government authority has the authority to direct the activities of local government bodies as well as permission to use in relation to its organs emergency personnel supervision measures. Considerations in this area are comparative in nature and include the provisions of the law governing the functioning of public administration in terms of the standard functioning of the state, when there is no threat of a special situation. The paper concludes with a summary and proposals which is an effect of the analysis carried out in the article.

Keywords: local government, states of emergency, legitimacy.

DOI:10.7862/rz.2013.hss.50

Tekst złożono w redakcji: październik 2013.

Przyjęto do druku: grudzień 2013. 